\title{
Analysis of the Tooth Length of Maxillary Incisors in Indonesian Mongoloid Race Population Based on Periapical Radiography
}

\author{
Dewi Kartika \\ Department of Oral Radiology \\ Faculty of Dentistry, Universitas Sumatera Utara \\ Medan, Indonesia \\ d_weex@yahoo.co.id
}

\author{
Fitri Yunita Batubara \\ Department of Conservative Dentistry \\ Faculty of Dentistry, Universitas Sumatera Utara \\ Medan, Indonesia
}

\begin{abstract}
Accurate assessment of the tooth length of maxillary incisor determines the success and prognosis of an endodontic treatment outcome. Periapical radiography is a method that can be used in determining the tooth length. This study was done to determine the average of the tooth length of maxillary incisors radiographically. Descriptive with cross sectional approach was used using eighty samples and samples selected by purposive sampling and the data were collected by questionnaire and x-ray photographs using periapical radiography. The research was conducted in Radiology Unit, Dental Hospital, Faculty of Dentistry, Universitas Sumatera Utara, on July and September 2017. The tooth length of maxillary incisors in Indonesian Mongoloid races population radiographically was $21-22 \mathrm{~mm}$ and all incisors had a single root $(100 \%)$. It can be concluded that average of the tooth length of maxillary central incisor radiographically is $22.03 \mathrm{~mm}$ and lateral incisor is $\mathbf{2 1 . 2 3}$ mm.
\end{abstract}

Keywords-tooth length, maxillary incisor, periapical radiography

\section{INTRODUCTION}

The knowledge of the tooth is important for dentists before endodontic treatment, especially to determine the working length. Tooth length and number of roots is one part of the external morphology. Errors in the determination of tooth length may cause endodontic instruments to go beyond the apical foramen, resulting in extravasation of irrigating solutions and restorative material into the periradicular tissues [1].

Periapical radiography is a commonly used radiograph during endodontic treatment. The use of periapical radiographs before, during, and after treatment is essential in order to identify and monitor anatomical details, canal length, obturation quality, and tooth and bone pathology [2].

Most of the available literature shows that endodontic treatments are frequently performed in maxillary incisors [3-5]. Research published by Ingle \& Bakland was done in Caucasian people, and there is no information available supporting the use of tooth length in non-Caucasian especially in Malayan Mongoloid sub races. Therefore researchers are interested in conducting a research on the tooth length of maxillary incisors in Indonesian Mongoloid race population by using periapical radiography.

\section{MATERIALS AND METHODS}

The method of this research is descriptive with cross sectional approach. Eighty samples are selected from a population of Mongoloid race in the city of Medan, Indonesia. Inclusion criteria were aged 18-24 years and a pure from Mongoloid race for two generations. Exclusion criteria were fractured tooth, tooth with pulpitis, tooth that has undergone endodontic and orthodontic treatment. This research used purposive sampling and the data were collected from questionnaires. Periapical radiography technique was done in the maxillary incisor on right and left side. The length of incisors was measured using a viewer box and a digital caliper to an accuracy of $0.01 \mathrm{~mm}$. The entire tooth length was measured at its longest point from the incisal tip to the root apex.

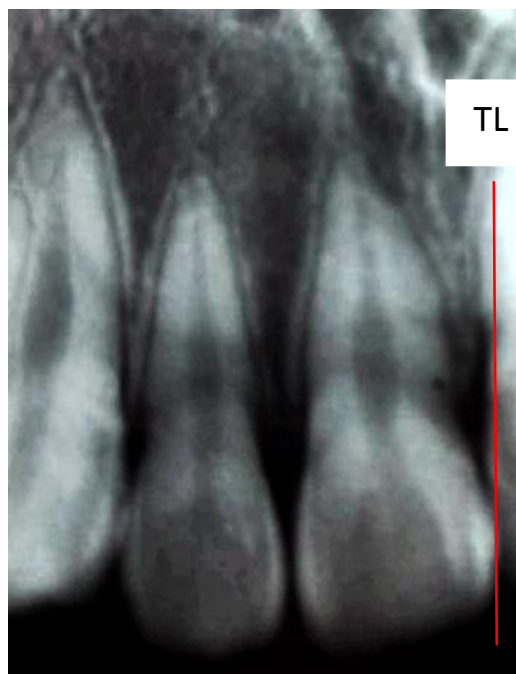

Figure 1. The method of measurement the tooth length (TL) 
III. RESULT

TABEL 1. THE PERCENTAGE OF THE NUMBER OF MAXILLARY INCISOR ROOTS

\begin{tabular}{|c|c|c|c|}
\hline \multirow{2}{*}{ No } & The teeth & \multicolumn{2}{|c|}{ Number of roots (\%) } \\
\cline { 3 - 4 } & & $\mathbf{1}$ (one) & $\begin{array}{c}>1 \text { (More than } \\
\text { one) }\end{array}$ \\
\hline 1 & Maxillary central incisor & $100 \%$ & - \\
\hline 2 & Maxillary lateral incisor & $100 \%$ & - \\
\hline
\end{tabular}

TABLE 2. THE AVERAGE OF THE LENGTH OF MAXILLARY INCISOR TEETH

\begin{tabular}{|c|l|c|}
\hline No & The teeth & Average of the length $(\mathbf{m m})$ \\
\hline 1 & Maxillary central incisor & 22.03 \\
\hline 2 & Maxillary lateral incisor & 21.23 \\
\hline
\end{tabular}

\section{DISCUSSION}

The population investigated in this study consisted of the population from Mongoloid races in Medan city, Indonesia, who were attending Dental Hospital, Faculty of Dentistry, Universitas Sumatera Utara, for the first time for a periodic checkup or required general dental treatment. The sample was selected according to the inclusion and exclusion criteria, periapical radiographic are performed on maxillary incisors on the left and right side.

Several studies have been done to assess the tooth length of maxillary incisors by using direct method and radiography technique. According Jayawardena et al, the mean of the tooth length on central incisors was $23.12 \pm 1.69 \mathrm{~mm}$ and lateral incisor was 22.05 \pm 1.47 . Their research sample is from Sri Lankan Sinhalese and the method was direct measurement with digital calipers on extracted teeth [6]. Another method is with cone beam computed tomography (CBCT) that Choi et al. used in samples from Korean population. The tooth length on that study is maxillary central incisor $22.8 \pm 1.15 \mathrm{~mm}$ and maxillary lateral incisor $21.6 \pm 1.0$ $\mathrm{mm}$ [7]. Research by Harris et al showed the tooth length of central incisor was $26.26 \pm 2.49 \mathrm{~mm}$ (males) and $25.21 \pm 2.14 \mathrm{~mm}$ (females), and lateral incisor was $25.15 \pm 2.42 \mathrm{~mm}$ (males) and $23.78 \pm 1.95 \mathrm{~mm}$ (females). Periapical radiography method was used and the samples are White American adults [8].

In the present study, samples were obtained from Mongoloid race and method was done using periapical radiography. All sample had a single root (100\%). The length tooth of maxillary central incisors was $22.03 \mathrm{~mm}$ and lateral central incisor was $21.23 \mathrm{~mm}$. The tooth length in this study was not much different from the study done by Choi et al. but differs from the study done by Jayawardena et al. and Harris et al. According to Edgcomb et al., the root length of Asian teeth is shorter than Caucasian, Hispanic, and African American. The difference generally occurs in the maxillary central incisors, the mandibular central and lateral incisors and mandibular second premolars [9].

In conclusion, the average of the tooth length of maxillary central incisor radiographically is $22.03 \mathrm{~mm}$ and lateral incisor is $21.23 \mathrm{~mm}$. The races can influence the tooth length and periapical radiography can be used to estimate the tooth length better than other two dimensional radiography.

\section{ACKNOWLEDGEMENT}

The authors are very grateful to all participants in this study. It was funded by Penelitian Talenta Universitas Sumatera Utara 2017.

\section{REFERENCES}

[1] M.D. Basso, F. Jeremias, R.C.L. Cordeiro, L. Santos-Pinto, "Digital radiography for determination of primary tooth length: In vivo and ex vivo studies," The Scientific World Journal, pp. $1-5,2015$.

[2] H.M.A. Ahmed, "Guidelines to enhance the interpretation of two-dimensional periapical radiographic images in endodontics," EJGD., vol. 4(3), pp. 106-112, 2015.

[3] A. Hoseini, A. Abbaszadegan, "Endodontic treatment of a maxillary lateral incisor with two roots; A case report with 6 months follow-Up,” J. Dent. Shiraz Univ. Med. Sci., vol. 15(4), pp. 204-207, 2014

[4] E.C. Sponchiado, H.A.A.Q.I. Ismail, M.R.L.B. Braga, F.K. de Carvalho, C.A.C.G.S. Simoes, "Maxillary central incisor with two root canals: a case report," J. Endod., vol. 32, pp. 1002 1004, 2006.

[5] M. Sheikh-Nezami, N. Mokhber, "Endodontic treatment of a maxillary central incisor with three root canals," J. Oral Sci. vol. 49(3), pp. 245-7, 2007.

[6] C.K. Jayawardena, A.P. Abesundara, D.C. Nanayakkara, M.S. Chandrasekara, "Age-related changes in crown and root length in Sri Lankan Sinhales,” J. Oral Sci., vol. 51, pp. 587-592, 2009.

[7] S.H. Choi, J.S. Kim, C.S. Kim, H.S. Yu, C.J. Hwang, "Conebeam computed tomography for the assessment of root-crown ratios of the maxillary and mandibular incisors in a Korean population,” Korean J. Orthod., vol. 47(1), pp. 39-49, 2017.

[8] E.F. Harris, W.M. Couch, "The relative sexual dimorphism of human incisor crown and root dimensions," Dental Anthropology, vol. 19(3), pp. 87-95, 2006.

[9] K. Edgcomb, E. BeGole, C. Evans, B. Jhonson, X. Luan, "Prevalence of short dental roots in four ethnic groups in an orthodontic population," Dental Anthropology, vol. 24(1), pp. $11-15,2011$ 